\title{
FRANÇOIS RABELAIS, CEuvres complètes: tome I et II
}

\section{Michele Mastroianni}

\section{OpenEdition \\ Journals}

\section{Edizione digitale}

URL: https://journals.openedition.org/studifrancesi/44883

DOI: $10.4000 /$ studifrancesi.44883

ISSN: 2421-5856

\section{Editore}

Rosenberg \& Sellier

\section{Edizione cartacea}

Data di pubblicazione: 1 août 2021

Paginazione: 360

ISSN: 0039-2944

\section{Notizia bibliografica digitale}

Michele Mastroianni, «Françoıs rabelais, EEuvres complètes: tome I et Il», Studi Francesi [Online], 194 (LXV

| II) | 2021, online dal 01 septembre 2021, consultato il 15 octobre 2022. URL: http://

journals.openedition.org/studifrancesi/44883 ; DOI: https://doi.org/10.4000/studifrancesi.44883

Questo documento è stato generato automaticamente il 15 octobre 2022.

\section{(c)}

Creative Commons - Attribuzione - Non commerciale - Non opere derivate 4.0 Internazionale - CC BYNC-ND 4.0

https://creativecommons.org/licenses/by-nc-nd/4.0/ 


\title{
FRANÇOIS RABELAIS, Euvres complètes: tome I et II
}

\author{
Michele Mastroianni
}

\section{NOTIZIA}

FRANÇOIS RABELAIS, CEuvres complètes: tome I et II, éd. P. Jourda, Paris, Classiques Garnier, 2020, «Classiques Jaunes» 485, 632 e 611 pp.

1 Annotata e introdotta da uno studio che contestualizza l'autore servendosi di dati e di lavori precedenti, è questa un'agile edizione ad uso in particolare di docenti universitari che intendano proporre all'attenzione dei giovani un autore tanto complesso come Rabelais. Nell'introduzione (pp. I-XLVIII), dati biografici, tematici e storici inquadrano sinteticamente uno dei titani della storia europea rinascimentale, mentre una bibliografia di base serve ad orientare sugli studi più recenti o sui lavori che l'editore ritiene più importanti. Certo è che la monumentale edizione di Mireille Huchon resta un punto fermo su Rabelais per erudizione, precisione e ricchezza indiscutibile di dati che, al momento, vanificano gli sforzi di chi pretende offrire un nuovo strumento critico sull'opera rabelaisiana. 